\title{
ANALISIS FAKTOR-FAKTOR PEMBENTUK CAMELS PADA PERBANKAN YANG TERDAFTAR DI BURSA EFEK INDONESIA
}

\author{
Sri Hermuningsih \\ Fakultas Ekonomi, Universitas Sarjanawiyata Tamansiswa \\ Yogyakarta \\ hermun_feust@yahoo.co.id
}

\section{ABSTRACT}

The aims of this study is to determine the major factors that form the performance of the Banking CAMELS listed in Indonesia Stock Exchange. The population in this study are all banking companies listed on the Stock Exchange in 2011-2012.The sampling method used in this study was purposive sampling method with the criteria is listed for 2 years. Samples were worth using as much as 72 recordable banking. The method of analysis using factor analysis with SPSS. The results showed that the 26 variables used as a proxy variable rate shaper CAMELS, 26 comunalities pass the test but there are two ratios that do not enter the group most variables, is debt management and CAR.

Keywords: CAMELS, factor analysis, financial performance

\section{PENDAHULUAN}

\subsection{Latar belakang}

Industri Perbankan memegang peranan penting bagi pembangunan ekonomi sebagai Financial Intermediary atau perantara pihak yang kelebihan dana dengan pihak yang membutuhkan dana (Mahardian, 2008). Bank dikenal sebagai lembaga keuangan yang kegiatan utamanya yaitu menghimpun dana dari masyarakat, menyalurkan dana kepada masyarakat, dan melakukan jasajasa lain dibidang perbankan. Atau dengan kata lain bank sebagai lembaga yang berperan sebagai perantara keuangan (financial intermediary), yaitu perantara antara pihak-pihak yang memiliki kelebihan dana dengan pihakpihak yang membutuhkan dana. Oleh karena itu bank harus dapat menjaga kepercayaan masyarakat dengan menjamin tingkat likuiditas juga beroperasi secara efektif dan efisien untuk mencapai profitabilitas yang tinggi.Kondisi perbankan ini mendorong pihak-pihak yang terlibat didalamnya untuk melakukan penilaian atas kesehatan bank. Salah satu pihak yang perlu mengetahui kinerja dari sebuah bank adalah investor sebab semakin baik kinerja bank tersebut maka jaminan keamanan atas dana yang diinvestasikan juga semakin besar. Dengan menggunakan rasio keuangan, investor dapat mengetahui kinerja suatu bank.Penilaian kinerja perbankan dapat dilakukan dengan beberapa cara, salah satunya adalah menggunakan rasio CAMELS yang terdiri dari Capital, Asset Quality, Management, Earning, Liquidity dan Sensitivity to Market Risk. 
JURNAL

MANAJEMEN

INDONESIA

Vol. 15 - No. 1

April 2015
Penelitian terdahulu melakukan penelitian tentang hubungan antara rasio CAMEL dengan kinerja perusahaan, antara lain Puspitasari (2003) menyatakan bahwa rasio CAMEL merupakan faktor pembentuk kinerja bank di Indonesia dengan 23 rasio. Khasanah (2010) meneliti pengaruh rasio CAMEL terhadap kinerja perusahaan, hasil penelitian adalah terdapat pengaruh yang signifikan rasio CAMEL terhadap kinerja perbankan yang diproyeksikan dengan Net Profit Margin. Defrio dan Meiranto (2013), menyatakan bahwa bahwa dari 26 rasio pembentuk CAMELS, terdapat 25 rasio yang signifikan sebagai pembentuk kinerja perbankan dan 18 rasio diantaranya merupakan faktor permanen pembentuk kinerja perbankan. Delapan belas rasio tersebut adalah PR, CAR, RAR, DRR, APB, RORA, LEV, ROE, NIM, ROA, BOPO, NPM, PM, GPM, ALR, CASH, QUICK, dan IER.

\subsection{Tujuan Penelitian}

Tujuan penelitian ini adalah menganalisis faktor-faktor pembentuk CAMELS perbankan yang terdaftar di Bursa Efek Indonesia periode tahun 2011-2012 dengan menggunakan 26 rasio seperti yang dilakukan oleh Mahardian (2008).

\subsection{Rumusan masalah.}

Rumusan masalah dalam penelitian ini adalah faktor-faktor apakah pembentuk CAMELS perbankan yang terdaftar di Bursa Efek Indonesia periode tahun 2011-2012.

\section{LANDASAN TEORI}

\subsection{Perbankan}

Menurut Undang-Undang PerbankanNomor 10 Tahun 1998bank adalah badan usaha yang menghimpun dana dari masyarakat dalam bentuk simpanan dan menyalurkannya kepada masyarakat dalam bentuk kredit dan atau bentuk-bentuk lainnya dalam rangka meningkatkan taraf hidup rakyat banyak (Kasmir, 2011)

\subsection{Fungsi Perbankan}

Bank dapat berfungsi sebagai berikut (Budisantosa dan Nuritomo, 2014):

a. Agent of trust

Dasar utama kegiatan perbankan adalah kepercayaan (trust), baik dalam hal menghimpun dana maupun penyaluran dana. Masyarakat mau menitipkan dananya di bank apabila dilandasi adanya unsur kepercayaan. Masyarakat percaya bahwa uangnya tidak akan disalahgunakan oleh bank, uangnya akan dikelola dengan baik, bank tidak akan bangkrut, dan pada saat yang telah dijanjikan simpanan tersebut dapat ditarik kembali dari bank. Pihak bank sendiri akan mau menempatkan atau menyalurkan dananya pada debitur atau masyarakat apabila dilandasi adanya unsur kepercayaan. Pihak bank percaya bahwa debitur tidak akan menyalahgunakan pinjamannya, debitur akan mengelola dana pinjaman saat jatuh tempo, dan debitur mempunyai niat baik untuk mengembalikan pinjaman beserta kewajiban lainnya pada saat jatuh tempo. 
b. Agent of Development

Kegiatan perekonomian masyarakat di sektor moneter dan di sektor riil tidak dapat dipisahkan. Kedua sektor tersebut selalu berinteraksi dan saling mempengaruhi. Sektor riil tidak akan dapat berkinerja dengan baik apabila sektor moneter tidak bekerja dengan baik. Kegiatan bank berupa penghimpunan dan penyaluran dana sangat diperlukan bagi lancarnya kegiatan perekonomian di sektor riil. Kegiatan bank tersebut memungkinkan masyarakat melakukan kegiatan investasi, kegiatan distribusi, serta kegiatan konsumsi barang dan jasa, mengingat bahwa kegiatan investasi-distribusi-konsumsi tidak dapat dilepaskan dari adanya penggunaan uang. Kelancaran kegiatan investasi, distribusi, dan konsumsi ini tidak lain adalah kegiatan pembangunan perekonomian suatu masyarakat.

\section{c. Agent of Service}

Di samping melakukan kegiatan penghimpunan dan penyaluran dana, bank juga memberikan penawaran jasa perbankan yang lain kepada masyarakat. Jasa ditawarkan bank ini erat kaitannya dengan kegiatan perekonomian secara luas. Jasa ini antara lain dapat berupa jasa pengiriman uang, penitipan barang berharga, pemberian jaminan bank, dan penyelesaian tagihan.

\subsection{Kinerja Keuangan Perbankan}

Kinerja keuangan bank merupakan gambaran kondisi keuangan bank pada suatu periode tertentu baik mencakup aspek penghimpunan dana maupun penyaluran dananya. Kinerja menunjukkan sesuatu yang berhubungan dengan kekuatan serta kelemahan suatu perusahaan.Kinerja perusahaan dapat di ukur dengan menganalisa dan mengevaluasi laporan keuangan. Informasi posisi keuangan dan kinerja keuangan di masa lalu seringkali di gunakan sebagai dasar untuk memprediksi posisi keuangan dan kinerja di masa depan dan hal lain yang langsung menarik perhatian pemakai seperti pembayaran dividen, upah, pergerakan harga sekuritas dan kemampuan perusahaan untuk memenuhi komitmennya ketika jatuh tempo.

\subsection{Pengukuran Kinerja dengan rasio keuangan}

Penilaian kinerja keuangan dapat dinilai dengan perhitungan rasio keuangan. Rasio keuangan yang menghubungkan dua data keuangan (laporan keuangan), yaitu neraca dan laporan laba rugi. Nilai rasio keuangan tersebut yang nantinya dibandingkan dengan tolok ukur yang telah ada. Analisis dan interpretasi nilai rasio keuangan yang telah diperoleh dapat memberikan pandangan yang lebih baik dan mendalam tentang kinerja keuangan. Analisis kinerja keuangan bank mempunyai tujuan antara lain (Abdullah, 2005):(1)Untuk mengetahui keberhasilan pengelolaan keuangan bank terutama kondisi likuiditas, kecukupan modal dan profitabilitas yang dicapai dalam tahun berjalan maupun tahun sebelumnya. (2). Untuk mengetahui kemampuan bank dalam mendayagunakan semua aktiva yang dimiliki dalam menghasilkan profit

Salah satu model yang digunakan untuk mengukur kinerja perusahaan khususnya perbankan adalah rasio keuangan dengan CAMEL. Rasio ini terbagi menjadi 5 kategori yaitu Capital, Asset, Mangement, Earning dan Liquidity. CAMEL digunakan pertama kali di Amerika pada tahun 1980an. Namun di Indonesia baru digunakan setelah Peraturan Bank Indonesia melalui surat Keputusan Direksi BI No 30/11/KEP/DIR pada tahun 1997 dan Surat Keputusan 
JURNAL

MANAJEMEN

INDONESIA

Vol. 15 - No. 1

April 2015
Direksi BI No 30/277/KEP/DIR tahun 1998 tentang analisis CAMEL dikeluarkan. Peraturan ini kemudian diperbarui melalui Peraturan Bank Indonesia No 6/10/PBI/2004 pada tanggal 12 April 2004. Pembaruan ini menambahkan satu komponen dalam raso CAMEL, yaitu Sensitivitas terhadap resiko pasar. Penilaian tingkat kesehatan perbankan menjadi rasio CAMELS. Pada tanggal 25 Oktober 2011, Bank Indonesia mengeluarkan Surat Edaran Bank Indonesia No 13/24/DPNP tentang penilaian tingkat kesehatan Bank Umum. Pada surat edaran tersebut menggolongkan faktor penilaian menjadi hanya empat faktor (RGEC), yaitu (1) Profil resiko atau risk profile, (2)Good Corporate Governance (GCG), (3) Rentabilitas atau Earnings, dan (4) Permodalan atau Capital.

\subsection{Analisis Camels}

Analisis CAMELS digunakan untuk menganalisis dan mengevaluasi kinerja keuangan bank umum di Indonesia. CAMELS merupakan kepanjangan dari Capital (C), Asset Quality (A), Management (M), Earning (E), Liability atau Liquidity (L), dan Sensitivity to Market Risk (S). Analisis CAMELS diatur dalam Peraturan Bank Indonesia Nomor 6/10/PBI/2004 perihal sistem penilaian Tingkat Kesehatan Bank Umum dan Peraturan Bank Indonesia Nomor 9/1/PBI/2007 Tentang Sistem Penilaian Tingkat Kesehatan Bank Umum Berdasarkan Prinsip Syariah.

\subsection{Penelitian terdahulu}

Thomson (1991), menyatakan bahwa rasio keuangan model CAMEL mempunyai kekuatan untuk memprediksi kebangkrutan suatu bank dan rasio tersebut merupakan peringatan dini bagi kegagalan bank. Puspitasari (2003), menyatakan bahwa rasio CAMEL merupakan faktor pembentuk kinerja Bank di Indonesia dengan menggunakan 23 rasio. Prasnanugraha (2007), menunjukkan pengaruh yang signifikan antara kelima rasio di terhadap ROA yaitu $86,9 \%$.Khasanah (2010), net profit margin memiliki pengaruh yang signifikan dengan kinerja perbankan. Defrio dan Meiranto (2013), menemukan bahwa 25 rasio yang signifikan sebagai pembentuk kinerja perbankan dan 18 rasio diantaranya merupakan faktor permanen pembentuk kinerja perbankan. Peneliti terdahulu banyak melakukan penelitian tentang pengaruh rasio keuangan model CAMELS terhadap kinerja bank, namun masih relatif sedikit peneliti yang melakukan penelitian tentang faktor atau rasio apa yang paling utama mempengaruhi kinerja perbankan. Peneliti terdahulu memiliki asumsi yang berbeda-beda untuk memasukkan rasio-rasio CAMELS ke dalam golongan capital, asset, management, earning, liquidity dan sensitivity to market risk.

\section{METODE PENELITIAN}

\section{a. Populasi, Sampel dan Data}

Populasi penelitian adalah seluruh perbankan yang terdaftar di Bursa Efek Indonesia. Sampel dalam penelitian ini perbankan yang terdaftar di Bursa Efek Indonesia periode tahun 2010 - 2012. Pengambilan sampel dengan metode purposive sampling. Sampel perbankan yang memenuhi syarat ada 72 bank.

Dalam penelitian ini variabel yang diuji adalah rasio keuangan model CAMELS, yang di proksikan dengan beberap rasio sebagai berikut :

1) Permodalan (Capital): Merupakan aspek permodalan yang dimiliki oleh bank.

Jurnal Manajemen Indonesia 
CAR(Capital Adequacy Ratio) adalah perbandingan antara modal sendiri bank dengan kebutuhan modal yang tersedia setelah dihitung pertumbuhan risiko(margin risk) dari akibat yang berisiko

2) Kualitas Aset (Asset Quality): Merupakan penilaian jenis aset yang dimiliki oleh perbankan. NPL(Non Performing Loan) merupakan masalah yang sering terjadi akhir - akhir ini yang menyebabkan kredit macet yang akan mengurangi jumlah modal dan pendapatan bank. Semakin kecil NPL maka semakin baik bagi suatu bank.

3) Manajemen (Management): Kualitas manajemen dapat tercermin dari kualitas SDMnya dalam bekerja, pendidikan dan pengalaman dalam menangani berbagai kasus yang terjadi (Kasmir, 2011).

4) Rentabilitas (Earnings): Merupakan ukuran kemampuan bank dalam meningkatkan labanya atau bisa dikatakan untuk mengukur tingkat efisiensi usaha dan profitabilitas yang dicapai bank tersebut (Kasmir, 2011).

ROA (Return on Assets), merupakan rasio yang digunakan mengukur kemampuan bank menghasilkan keuntungan secara relatif dibandingkan dengan total asetnya. Semakin besar ROA semakin besar pula tingkat keuntungan yang dicapai bank tersebut dan semakin baik pula posisi bank dari segi penggunaan asset.

ROE (Return on Equity), merupakan perbandingan antara keuntungan yang diperoleh bank dengan total modal sendiri. Jadi, semakin besar ROE akan semakin baik bagi bank. NIM (Net Interest Margin), merupakan perbandingan antara pendapatan bunga bersih dengan rata - rata aktiva produktif.

5) Likuiditas (Liquidity) :Merupakan kemampuan bank untuk melunasi kewajiban jangka pendeknya tepat pada waktunya. Loan Deposit Ratio (LDR), merupakan usuran likuiditas dan tingkat efisiensi operasional yang dicapai bank dengan indikator BOPO

6) Sensitivitas terhadap Risiko Pasar (Sensitivity to Market Risks) : Variabel ini merupakan ukuran seberapa besar tingkat sensitivitas sebuah bank terhadap resiko pasar atau Market Risk. Resiko pasar itu sendiri merupakan akibat pergerakan harga pasar dari portofolio yang dimiliki oleh bank, dan dapat merugikan bank tersebut.

\section{b. Teknik Analisis}

Teknik analisis dalam penelitian ini menggunakan analisis faktor yaitu analisis yang bertujuan mencari faktor-faktor utama yang paling mempengaruhi variabel dependen dari serangkaian uji yang dilakukan atas serangkaian variabel independen sebagai faktornya

\section{i. Uji Asumsi Analisis Faktor}

Beberapa uji tersebut antara lain :

1) Uji analisis faktor harus menghasilkan angka extraction communalties $>0,60$.

2) Uji Bartlett test of sphericity, yang digunakan untuk mengetahui apakah ada korelasi yang signifikan antar variabel.

3) Uji Keisen-Meyers-Oklin (KMO)Measurement Sample of Adequacy), yang digunakan untuk mengukur kecukupan sampel dengan cara membandingkan besarnya koefisien korelasi yang diamati dengan koefisien parsialnya.

4) Latent Root Criterion dengan eigenvalue yang harus lebih besar dari 1, maka faktor tersebut dapat diterima atau signifikan.
JURNAL

MANAJEMEN

INDONESIA

Vol. 15 - No. 1

April 2015 
JURNAL

MANAJEMEN

INDONESIA

Vol. 15 - No. 1

April 2015
5) Uji Comunalities

Uji Comunalities digunakan untuk mengetahui seberapa besar kontribusi variabel tersebut terhadap faktor yang dibentuk. Nilai communalities ini sama pengertiannya dengan nilai koefisien determinasi pada model regresi

\section{ii. Variabel Penelitian dan Definisi Operasional Variabel}

Variabel yang diuji dalam penelitian ini adalah rasio keuangan model CAMELS, yang diproksikan dengan beberapa rasio sebagai berikut:

1) Aspek Capital diukur dengan sebagai berikut : a) Primary Ratio= Equity Capital/Total Asset. b) Risk Assets Ratio= Equity Capital/(Total Assets-Cash-Securities). c) CAR= Equity Capital/ ATMR. d) Deposit Risk Ratio= Equity Capital/Total Deposits

2) Assets diukur dengan cara sebagai berikut : a) Return on Risk Assets: EBIT/ Risk Assets. b) Assets Utilization= (Operating Income+ Non Operating Income)/Total Assets. c) APB= Aktiva Produktif Bermasalah/Total Aktiva x 100\%. d) Non Performing Loan=Kredit Bermasalah/Kredit yang Disalurkan.

3) Aspek management diukur dengan cara sebagai berikut: a) Leverage Management=Debt/ Equity. b) Cost Debt Ratio=Total Interest/ Total Debt. c) Spread Management= Return on Total Assets/Cost Debt Ratio. d) Debt Management= Leverage Management x Spread Manegement

4) Aspek earning diukur dengan cara sebagai berikut: a) Gross Profit Margin= (Operating Income-Operating Expenses)/Operating Income. b) Profit Margin=EAT/ Total Loan. c) Return On Equity=EAT/ Equity Capital. d) Return On Total Assets=EAT / Total Assets.e) Return On Assets=EAT/Total Assets. f) Gross Yield On Total Assets= Operating Income/ Total Assets. g) Net Profit Margin= Net Income/ Operating Income.

h) Net Interests Margin=Total Interests/ Total Loan. i) BOPO= Beban Operasional/Pendapatan Operasional

5) Aspek likuiditas diukur dengan cara sebagai berikut: a) Cash Ratio= Cash/Short Term Borrowing. b) Quick Ratio= Cash/Total Deposits. c) Loan to Deposit Ratio= Total Loans/Total Deposit. d) Asset to Loan Ratio= Total Loans/Total Assets

6) Tingkat sensitivitas terhadap resiko pasar diukur dengan cara sebagai berikut : Interest Expense Ratio = Interest Expense/Total Deposits

\section{HASIL DAN PEMBAHASAN}

\section{1) Statistik Deskriptif}

Dari tabel 1 pada variabel Capital, rasio PR, RAR, CAR, DRR masingmasing memiliki nilai rata-rata 0,$184981 ; 0,1668 ; 0,4936 ; 0,2619$, nilai minimum 0,0210; -0,02;0,02;0,03 nilai maksimum 0,9448; 2,22; 0,98; 3,25. Variabel Asset, rasio RORA, AUR, APB, NPL masing-masing memiliki nilai ratarata $2.2368 ; 0,14239 ; 1548 ; 0222$ nilai minimum $-0,84 ; 0,00 ; 0.01 ; 0,01$, nilai maksimum 8.20;0,642;0, 54; 0,06. Variabel management, rasio LEV, CDR, SPRD, DEBT masing-masing memiliki nilai rata-rata 3.7244; 0, 1074; 0, 1377; 29.2717 nilai minimum0,00;0,04; -0,19; 3,07 nilai maksimum 9,88;0,43;0,37; 58,98. Variabel Earning, rasio GPM, PM, ROE, ROTA, ROA, GOTA, NPM, NIM, BOPO masing-masing memiliki nilai rata-rata 2.1916; 0, 0184;0,2727; 0, .2727; 
0,$2727 ; 0,1048 ; 0,1628 ; 0,1628 ; 0,4948$ nilai minimum $1.18 ;-0,02 ;-0,29 ;-$ 0,$02 ;-0,02 ; 0,00 ;-0,21 ; 0,04 ; 0,26$ nilai maksimum $3.82 ; 0,05 ; 3,12 ; 3,45$; 2,$34 ; 0,91,0,42 ; 0,85$. Variabel likuiditas, rasio CASH, LDR, QUICK, ALR masingmasing memiliki nilai rata-rata 0,$9617 ; 0,0206 ; 1,0977 ; 0.7055$ nilai minimum 0,$15 ; 0,00 ; 0,12 ; 0,00$ nilai maksimum 3,$31 ; 0,10 ; 1,53 ; 0,92$. Variabel sensitivitas, rasio IER memiliki nilai rata-rata 0,1179 nilai minimum 0,01 nilai maksimum 0,44.

\begin{tabular}{|c|c|c|c|c|c|}
\hline & $\mathrm{N}$ & Minimum & Maksimum & Rata-rata & Standar devias \\
\hline PR & 72 & 0,0210 & 0,9448 & 0,184981 & 0,2145761 \\
\hline RAR & 72 & $-0,02$ & 2,22 & 0,1668 & 0,27876 \\
\hline CAR & 72 & 0,02 & 0,98 & 0,4936 & 0,28390 \\
\hline DRR & 72 & 0,03 & 3,25 & 0,2629 & 0,40254 \\
\hline RORA & 72 & $-0,84$ & 8,20 & 2,2368 & 1,77015 \\
\hline AUR & 72 & 0,000 & 0,642 & 0,14239 & 0,089442 \\
\hline APB & 72 & 0,01 & 0,54 & 0,1548 & 0,13711 \\
\hline NPL & 72 & 0,01 & 0,06 & 0,0222 & 0,01474 \\
\hline LEV & 72 & 0,00 & 9,88 & 3,7244 & 2,82484 \\
\hline CDR & 72 & 0,04 & 0,43 & 0,1074 & 0,04744 \\
\hline SPRD & 72 & $-0,19$ & 0,37 & 0,1377 & 0,10268 \\
\hline DEBT & 72 & 3,07 & 58,93 & 29,2717 & 15,80990 \\
\hline GPM & 72 & 1,18 & 3,82 & 2,1916 & 0,66374 \\
\hline PM & 72 & $-0,02$ & 0,05 & 0,0184 & 0,01377 \\
\hline ROE & 72 & $-0,29$ & 3,12 & 0,2727 & 0,54117 \\
\hline ROTA & 72 & $-0,02$ & 3,45 & 0,1215 & 0,44311 \\
\hline ROA & 72 & $-0,02$ & 2,34 & 0,1119 & 0,36065 \\
\hline GOTA & 72 & 0,00 & 0,91 & 0,1048 & 0,13686 \\
\hline NPM & 72 & $-0,21$ & 0,42 & 0,1628 & 0,12122 \\
\hline NIM & 72 & 0,04 & 0,43 & 0,1087 & 0,04736 \\
\hline BOPO & 72 & 0,26 & 0,85 & 0,4948 & 0,13822 \\
\hline CASH & 72 & 0,15 & 3,31 & 0,9617 & 0,60666 \\
\hline QUICK & 72 & 0,00 & 0,10 & 0,0206 & 0,01563 \\
\hline LDR & 72 & 0,12 & 1,53 & 1,0977 & 0,15664 \\
\hline ALR & 72 & 0,00 & 0,92 & 0,7055 & 0,31599 \\
\hline IER & 72 & 0,01 & 0,44 & 0,1179 & 0,05053 \\
\hline $\begin{array}{l}\text { Valid N } \\
\text { (listwise) }\end{array}$ & 72 & & & & \\
\hline
\end{tabular}

Tabel 1.

Statistik Deskriptif 
JURNAL

MANAJEMEN

INDONESIA

Vol. 15 - No. 1

April 2015

Tabel 2.

KMO and

Bartlett's Test a. Uji Analisis Faktor

b. Uji Bartlett test of sphericity

Berdasarkan hasil analisis dengan menggunakan program SPSS versi 16 diperoleh output sebagai berikut :

\begin{tabular}{lcc}
\hline Kaiser-Meyer-Olkin Measure of Sampling Adequacy. & 0,512 \\
\hline Bartlett's Test of Sphericity & Approx. Chi-Square & 1,7703 \\
& df & 0,325 \\
& Sig. & 0,000 \\
\hline
\end{tabular}

Dari tabel 2 KMO and Bartlett's Test menunjukkan bahwa nilai Kaiser-Meyer-Olkin Measure of Sampling Adequacy sebesar 0,512, artinya bahwa sampel yang digunakan dalam penelitian ini memilik reliabilitas yang sedang dan hasil analisis cukup baik karena nilainya diatas 0,5. Nilai Bartlett's Test of Sphericity sebesar 1,7703 dengan nilai signifikansi 0,00 , yang menjelaskan bahwa faktor pembentuk variabel ini sudah baik dan smpel sudah memadai untuk dianalisis uji lanjut.

c. Uji Keisen-Meyers-Oklin (KMO)

Dari hasil uji anti image matrices bahwa angka MSA sudah memenuhi batas 0,05 . Dengan demikian semua variabel bisa di prediksi dan dianalisi lanjut atau dapa dinyatakan semua faktor telah valid dan relevan

b. Uji Latent Root Criiterion

Uji Latent Root Criiterion menggunakan nilai Eigenvalue dan \% variance sebagai dasar dalam menentukan faktor mana yang dianggap layak untuk diambil sebagai faktor pengamatan. Nilai dari Eigenvalue menunjukkan urutan tingkat kepentingan suatu faktor. Semakin besar nilai Eigenvalue, maka faktor tersebut dianggap semakin penting. Batasan minimal Eigenvalue yang dapat diambil sebagai faktor pengamatan adalah lebih besar dari 1 . Sedangkan \% variance menunjukkan kemampuan dari faktor-faktor tersebut untuk menjelaskan perubahan dari variabel yang diteliti. Nilai dari \% commulative menunjukkan akumulasi kemampuan keseluruhan faktor-faktor tersebut untuk menjelaskn variabel yang diteliti ( Hair, 1995) 


\begin{tabular}{lccc}
\hline \multirow{2}{*}{ Komponen } & \multicolumn{3}{c}{ Eigenvalue } \\
\cline { 2 - 4 } & Total & \% dari Variance & \% Akumulasi \\
\hline 1 & 4,542 & 17,471 & 17,471 \\
2 & 3,577 & 13,756 & 31,227 \\
3 & 3,113 & 11,972 & 43,199 \\
4 & 2,602 & 10,007 & 53,206 \\
5 & 1,625 & 6,251 & 59,457 \\
6 & 1,523 & 5,859 & 65,316 \\
7 & 1,389 & 5,342 & 70,658 \\
8 & 1,263 & 4,856 & 75,514 \\
9 & 1,122 & 4,315 & 79,829 \\
\hline
\end{tabular}

JURNAL

MANAJEMEN

INDONESIA

Vol. 15 - No. 1

April 2015

Dari tabel 3 diketahui bahwa nilai Eigenvalue terbesar adalah 4,542 dengan $\%$ variance sebesar $17,471 \%$ akumulasi 17,471 . Artinya bahwa secara akumulasi faktor pertama mampu menjelaskan variabel yang diteliti sebesar $17,471 \%$. Nilai Eigenvalue berturut-turut sebesar 3,577 dengan \%variance sebesar $13,756 \%$ akumulasi 31,227. Artinya bahwa secara akumulasi faktor kedua mampu menjelaskan variabel yang diteliti sebesar 31,77\% Nilai Eigenvalue sebesar 3,113 dengan \% variance sebesar 11,972 \% akumulasi 43,199 Artinya bahwa secara akumulasi faktor ketiga mampu menjelaskan variabel yang diteliti sebesar 11,972 \% Nilai Eigenvalue sebesar 2,602 dengan \% variance sebesar 10,007 \% Akumulasi 53,206. Artinya bahwa secara akumulasi faktor ke empat mampu menjelaskan variabel yang diteliti sebesar $53,206 \%$. Nilai Eigenvalue sebesar 1,625 dengan \% variance sebesar $6,251 \%$ akumulasi 59,457. Artinya bahwa secara akumulasi faktor ke lima mampu menjelaskan variabel yang diteliti sebesar $59,457 \%$ Nilai Eigenvalue sebesar 1,523 dengan \% variance sebesar 5,859\% akumulasi 65,316 Artinya bahwa secara akumulasi faktor ke enam mampu menjelaskan variabel yang diteliti sebesar $65,316 \%$. Nilai Eigenvalue sebesar 1,389 dengan \% variance sebesar 5,342 \% akumulasi 70,658. Artinya bahwa secara akumulasi faktor ke tujuh mampu menjelaskan variabel yang diteliti sebesar $70,658 \%$. Nilai Eigenvalue sebesar 1,263 dengan \% variance sebesar 4,856 \% akumulasi 75,514. Artinya bahwa secara akumulasi faktor ke delapan mampu menjelaskan variabel yang diteliti sebesar 75,514 \%Eigenvalue sebesar 1,122 dengan \% variance sebesar 4,315 \% akumulasi 79,829 Artinya bahwa secara akumulasi faktor ke sembilan mampu menjelaskan variabel yang diteliti sebesar $79,829 \%$

\section{e. Uji Comunalities}

Uji Comunalities digunakan untuk mengetahui seberapa besar kontribusi variabel tersebut terhadap faktor yang dibentuk. Nilai communalities ini sama pengertiannya dengan nilai koefisien determinasi pada model regresi. 
JURNAL

MANAJEMEN

INDONESIA

Vol. 15 - No. 1

April 2015

Tabel 4.

Communalities

\begin{tabular}{lcc}
\hline & Initial & Loading Factor \\
\hline PR & 1,000 & 0,832 \\
RAR & 1,000 & 0,939 \\
CAR & 1,000 & 0,582 \\
RORA & 1,000 & 0,606 \\
AUR & 1,000 & 0,716 \\
APB & 1,000 & 0,637 \\
DRR & 1,000 & 0,904 \\
NPL & 1,000 & 0,648 \\
LEV & 1.000 & 0,789 \\
CDR & 1.000 & 0,960 \\
SPRD & 1.000 & 0,826 \\
DEBT & 1.000 & 0,533 \\
GPM & 1.000 & 0,918 \\
PM & 1.000 & 0,785 \\
ROE & 1.000 & 0,850 \\
ROTA & 1.000 & 0,885 \\
ROA & 1.000 & 0,966 \\
GOTA & 1.000 & 0,548 \\
NPM & 1.000 & 0,843 \\
NIM & 1.000 & 0,967 \\
BOPO & 1.000 & 0,854 \\
CASH & 1.000 & 0,708 \\
QUICK & 1.000 & 0,839 \\
LDR & 1.000 & 0,852 \\
ALR & 1.000 & 0,814 \\
IER & 1.000 & 0,954 \\
Extraction Method: Principal & \\
Component Analysis. & \\
\hline & & \\
\hline
\end{tabular}

Dari tabel 4 menunjukkan bahwa rasio-rasio yang memiliki nilai comunilities dibawah angka 0,6 adalah Debt Management sebesar 0,533 dan CAR sebesar 0,582. Artinya dari 26 rasio lolos uji communalities tetapi rasio Debt management dan CAR tidak masuk kelompok most variables. Variabel Primary Ratio, sebesar 0,832, artinya bahwa 83,2 \% varian dari variabel Primary Ratio bisa dijelaskan oleh faktor yang terbentuk. Semakin tinggi communalities maka semakin tinggi pengaruhnya terhadap faktor yang terbentuk 


\section{KESIMPULAN}

a. Hasil pengujian dengan analisis faktor-faktor pembentuk CAMELS perbankan yang terdaftar di Bursa Efek Indonesia menunjukkan bahwa 26 variabel yang digunakan sebagai proksi variabel pembentuk CAMELS,26 rasio lolos uji comunalities. Dapat disimpulkan bahwa 26 variabel secara signifikan dapat digunakan sebagai faktor pembentuk kinerja perbankan.

b. Faktor utama pembentuk CAMELS perbankan yang terdaftar di Bursa Efek Indonesia periode tahun 2011-2012adalah Net Profit Margin sebesar 0,841 (84,1 \%); Return On Assets (ROA) sebesar 0,840 (84,0 \%); Spread Management (SPRD) sebesar 0,825 (82,5\%); Risk Assets Ratio (RAR) sebesar 0,829 (82,9\%); Net Interests Margin (NIM) sebesar 0799 (79,9\%); Return On Total Assets (ROTA) sebesar 0,794 (79,4\%); Interest Expense Ratio (IER) sebesar 0,793 (79,3 $\%)$; Ratio Cost Debt (CDR) sebesar 0,790 (79,0\%); Primary Ratio (PR) sebesar 0,739 (73,9 \%); Return On Equity (ROE) sebesar 0,708 (70,8 \%); Profit Margin (PM) sebesar 0,703 (70,3\%).

\section{SARAN}

Dengan adanya kerbatasan dalam penelitian ini, maka bagi peneliti selanjutnya untuk menambah periode pengamatan dan rmemasukkan faktor eksternal seperti peraturan pemerintah, perkembangan teknologi informasi, dan persaingan pasar.

\section{DAFTAR PUSTAKA}

Abdullah, Faizal. 2005. Manajemen Perbankan (Teknik Analisis Kinerja Keuangan Bank). Malang: UMM Press

Budisantosa dan Nuritomo. 2014. Bank dan Lembaga Keuangan lainnya. Salemba Empat Hair. 1995.Multivariat data Analysis. New Jersey: Englewood Clift

Kasmir. 2011. Bank dan Lembaga Keuangan lainnya. Jakarta: PT. Raja Grafindo Persada Khasanah, I.2010. Pengaruh Rasio Camel Terhadap Kinerja Perusahaan Perbankan yang Teraftar Di BEI. Semarang: Universitas Diponegoro.

Mahardian, Pandu, 2008. Analisis Pengaruh Rasio CAR, BOPO, NPL, NIM dan LDR terhadap Kinerja Keuangan Perbankan. Tesis tidak dipublikasikan,Universitas Diponegoro

Defrio, Mayco dan Wahyu Meiranto. 2013. Analisis Faktor-faktor pembentuk kinerja (CAMELS) Pada Perusahaan Perbankan Indonesia.Diponegoro Journal of Accounting. Vol. 2, No. 2, pp. 2337-3806

Merkusiwati, Ni Ketut Lely Aryani. 2007. Evaluasi Pengaruh CAMEL Terhadap Kinerja Perusahaan. Buletin Studi Ekonomi. Vol. 12, No. 1, pp. 100

Mahardian, Pandu, 2008. Analisis Pengaruh Rasio CAR, BOPO, NPL, NIM dan LDR Terhadap KinerjaKeuangan Perbankan,(Studi Kasus Perusahaan Perbankan Yang Tercatat Di BEJ Periode Juni 2002 - Juni 2007). Tesis Tidak Dipublikasikan, Universitas Diponegoro

Peraturan Bank Indonesia melalui surat Keputusan Direksi BI No 30/11/KEP/DIR pada tahun 1997 dan Surat Keputusan Direksi BI No 30/277/KEP/DIR tahun 1998. Analisis CAMEL dikeluarkan. 
Puspitasari, E. 2003. Analisis Faktor-faktor Pembentuk Kinerja Bank Pada Perbankan

JURNAL Indonesia.Tesis Tidak Dipublikasikan. Program Studi Magister Akuntansi Universitas Diponegoro

MANAJEMEN INDONESIA

Thomson.J.B. 1991. Predicting bank Failures in the 1980s. Federal Reserve bank of Cleveland. Economic Review. Vol. 27, p. 9-20

Vol. 15 - No. 1

April 2015

Jurnal Manajemen Indonesia 